\title{
Significance of Teachers and Education in Promoting National Economic Development: A Case Study of Pakistan
}

\author{
Farah Khan ${ }^{1}$, Muhammad Sofian Bin Omar Fauzee ${ }^{1} \&$ Yakob Daud $^{1}$ \\ ${ }^{1}$ School of Education and Modern Languages, CAS, Universiti Utara Malaysia, Malaysia \\ Correspondence: Muhammad Sofian Bin Omar Fauzee, School of Education and Modern Languages, CAS, \\ Universiti Utara Malaysia, Malaysia. E-mail: mohdsofian@uum.edu.my
}

\author{
Received: January 2, 2015 Accepted: January 13, 2015 Online Published: April 30, 2015 \\ doi:10.5539/ass.v11n12p290 URL: http://dx.doi.org/10.5539/ass.v11n12p290
}

\begin{abstract}
The key objective of the present paper is to highlight the consequence of education along with the importance of teacher in education and its overall influence on the national economic development Pakistan. It is crystal clear that the role of education and teachers has become more important in improving human capital and consequently has a positive impact on the national development and prosperity. The results of this study show that teachers in all level including primary school, middle school teacher and high school teacher play a positive and statistically significant role in promoting national economic development. Therefore, these findings have some important policy implications. The government of Pakistan at both the federal and provincial levels needs to formulate appropriate and education promoting oriented policy in order to encourage education and increase quality trained teachers in the country. Consequently, it will further help to promote overall economy performance and largely mitigate poverty and improve social welfare in the country.
\end{abstract}

Keywords: education, teachers role, national economic development, Pakistan

\section{Introduction}

Teachers in Islam are given a number of different titles such as Shaykh or "Aalim in Arabic. In Islam, the importance of teacher is highly valuable and visible. The holy prophet Hazrat Muhammad (PBUH) said that "It is compulsory for every Muslim men and women to acquire knowledge." The holy prophet Hazrat Muhammad (PBUH) tells the Muslims that seeking knowledge is an obligation for believing every men and women even if that means traveling to China. These ideals have led Muslims to travel in search of knowledge to study with various teachers throughout the world. Similarly, Hazrat Ali R. A. said "One who taught me a single word, made me his salve." Hence, role of the teacher comprises pedagogical, academic, and social. Teachers are representative of the society who teaches ethical guidelines. Nobody can have an impact more deep than that of teachers. Students deeply touch by the teacher's love, affection, character, competence, and his ethical commitment. Teachers are nation builders. Popular teacher becomes an ideal for his students. Students also try to observe their teacher in his manners, politeness, traditions, get up and his conversation style. Teacher is the pillar of the society and the country. No country can progress, without talented, noble and good teachers. Teacher impacts the young minds of-the youth. Teacher's devotion, love and martyrs show us the right track and it is our dear teachers who polish our personality, our character, and show us the right path which clues us to our final terminus. For the development of a country, great nations has to be paid special attention to education and learning as well as good morals, and it is impossible without the contribution of a humble teachers.

Good teacher is one who observes his purpose in teaching as existence one of deliverance rather than regulatory students. In the words of Datta (1988) "a profession is an occupation of a special kind three aspects of which are conventionally emphasized namely: expertise, self-determination and public identifying". In a study Shah (2002) notes his views that teacher education is that knowledge, ability and skill which is related to the life of "teacher as a teacher". According to Sarita and Tomar (2004) teaching is an artistic, intellectually demanding and pleasing job, so the values of this job must be too high. Expert can make teaching look easy though they have learned their abilities and enhanced them through practice, training, and evaluation. Initial training lays the foundation for succeeding professional and career development. Teacher education is very significant talent for conveying quality improvement in education. It is only teachers who have a vital role in the development of a nation. In teacher education, field many new tendencies and revolutions have appeared. In the area of teacher 
education there are new policies, procedures and practices (Rao \& Rao, 2005). In a similar way, according to Rashid, et al. (2014) teachers are not born but are created, their training and education both focuses and help to control the class for the improved and effective distribution of gratified. It is also invited the students about the critical nature of content which they want to put in exercise in the animate conditions.

The significance of education is crystal clear and proven also from Islam "To seek knowledge is a sacred duty; it is obligatory on every Muslim, male and female. The first word revealed of the Quran was "Iqra" READ: Seek knowledge! Educate yourselves! Be educated." Similarly, "are those equal, those who know and those who do not know?" (Surah Az-Zumr, ayat 9) "Allah grants wisdom to whom he pleases and to whom wisdom is granted indeed he receives an overflowing benefit" (Surah Al-Baqarah, ayat 269). Humans are different from other species because of education. It is the embodiment, the appearance and the personification of humankind. Satisfaction of the physical needs is only one factor of human presence, fulfillment of the reasoning, emotional and nonphysical wants is the second and possibly a more significant aspect of our survival. Education gives to the fulfillment of both the desires. Great philosophers and leaders have stressed the need and importance of education since old time. Every civilization and every society laid a finest on education. The civilizations whose realized it and sustained to progress in the educational fields were also the leaders of the world (Ahmed, 2000).

Obviously, education helps you to understand physically better, it assistances you to comprehend your potential, talents, abilities and qualities as a human being. Education introduces you to different religions, cultures, and thought. Education also provides a walking stone to the actual world; present numerous different courses on proper life planning, financial techniques, and personal development. In a study, Farah et al. (2014a: 912) notes that "Education plays a paramount role in the development of a society. Teachers are those selected people who having the candle of enlightenment, knowledge and the key to success. The success of a nation depends upon the success of education system, while the success of education system depends upon the quality of teachers, where, the quality of teachers based on the quality of teacher training." In another study by, Farah et al. (2014b) shed light on the significance of teacher education descriptively in the context of three countries namely Afghanistan, Iran and Pakistan. Similar, Muhammad and Chandra (2014), notes that Asian countries including Pakistan is suffered from corruption which affect the process of economic development and it need to be mitigated. It is also believed that less developed countries needs to invest more in education and training; consequently it will get better human capital and economic growth and development. So the ultimate result would be improved the level of social welfare.

According to the ASER (2013) report, there is total 3959 government/public and 1694 private schools exist in 138 rural districts of Pakistan. Where, $30-40 \%$ teachers of public schools have passed graduation as compared to $39 \%$ teachers of private schools. Likewise $40 \%$ of public school teachers had Bachelors in Education (B.Ed.) degrees; while in the private school this ratio is estimated 46\% (Government of Pakistan, Economy Survey 2013-14). Government of Pakistan, Economy Survey (2013-14) reveals that there were functional almost 158.6 thousands primary schools with 427.7 thousands teachers during 2012-13 at national level. At the same time as, in a total of 42.1 thousand middle schools where almost total 362.6 thousand teachers were working in the entire country during 2012-13. Similarly, a total of 489.6 thousand teachers were working in almost 29.8 thousand secondary schools in Pakistan during 2012-13. Further, at national level during 2012-13, a total of 130.1 thousand teachers were serviceable in a total of 4.9 thousand higher secondary schools and inter colleges in the whole country. In a similar vein, the total teachers during 2012-13 were recorded at 1.55 million as compared to 1.46 million during 2011-12, whereas it exposing a rise of 6.2 percent. However, it is expected that this number of teachers to be rise further up to 1.62 million during 2013-14.

The ultimate goal of every state is to ensure desirable level of national economic development. Where, the economy of Pakistan like other countries also confront of many administrative, economic, socio and political problems. Therefore, by prompting education, and human capital, it is hope that social welfare supposed to be increased and national development will be enhanced. Pakistan is a developing country where though natural resources are abundant but can utilize it due to lack of financial resources and human resources. In a study Muhammad and Salim (2014) reveals that Pakistan also suffers from inflation which needs to be controlled in order to boost economic development process. Therefore, development of human resources is indispensable for promoting national economic development and social welfare of Pakistan. The main objective of this study is to know about the importance of teachers, the importance of teachers training, the significance of education and analyze the role teacher education in social welfare promotion of Pakistan. This study will contribute on the role of teacher and education in the development and prosperity of Pakistan. 


\section{Review of Literature}

Numerous writers, authors and scholars have recognized different determining factor of education quality. The study of Cheng and Cheung (1997) reveals that quality of education is a set of components comprising input, process and output of education system. One another important model of quality of education has been given by UNICEF (2000) which includes five dimensions i.e. quality content, quality processes, quality learners, quality learning environments, and quality outcomes. Ozturk (2001) mentioned in his study that education in every sense is one of the major factors of development. In human capital no country can succeed maintainable economic development without considerable investment. According to him through education people improves understanding of themselves and world and also improves the quality of their lives. Education increases people's productivity, efficiency, creativity, vision and overall education plays a vital role in securing economic and social development and also improving income supply. Nonetheless, the importance of education in society is very necessary and cohering. In real sense, education is to civilize humanity, and to make life enlightened. It is very significant for the development of individual and whole society and it is also through education that man become broad-minded in his thinking, problem solving, socially and ethically rich, expressively and emotionally established, morally honest, mentally and spiritually aware, mentally and physically healthy and strong, horizon broad, self-confident, effectively social, mentally progressive, and tolerable level of behavior. Indeed it is difficult to define the quality of education mainly because of large number of investors involved in schooling and multifaceted nature of teaching-learning process (Mirza, 2003).

Education is extensively documented as an important to processes of poverty reduction. Burtch (2006) study indicates that education is an important force in economic, social, cultural and intellectual empowerment. According to Jaiyeoba (2007) its value in conveying about character and attitudinal change statuses as important as its ability to redesign human potentials for needed development. Lasker, et al. (2001), stated in his study that education is one of the machines to authorize people to take part in poverty lessening. Augmented the education is a resources to attain development and to solve the rural problems. Education and Poverty are inconsistently connected to each other: if one is enhanced, the other is reduced. It is observed that education is the most influential weapon in lessening poverty, raising economic growth, creating skillful human resource, producing a healthy and progressive social environment and also creating self-sufficient nations.

In a study Lin (2006) finds that primary, secondary and tertiary education has statistically positive influence on economic development and growth in Taiwan. Azam and Khattak (2009) find insignificant results on the human capital measured by secondary school enrolment on economic growth in Pakistan. Similarly, Huang, F., Jin, L., \& Sun, X. (2009) examine the long and short run interactional mechanism between higher education and economic growth in China over the period from1972 to 2007. The study finds that higher education has a positive and significant relationship with economic development measured by GDP per capita during the period under the study. In case of Guatemala, Loening, et al. (2010) observes that primary education is relatively more significant than secondary and tertiary education. The study of Shaihani, et al. (2011) indicates that in the short run merely secondary education has a statistically significant and positive impact on economic development of Malaysia, whereas the primary and tertiary education display inverse results.

The impact of human capital measured by secondary school on economic growth during 1995-2011 for Azerbaijan and Kazakhstan have been investigates and found positive significant relationship between these two variables (Azam, 2013). In a seven Asian countries study, Azam, et al. (2014) reveals that secondary school gross enrollment ratio as proxy for human capital has a positive and significant relationship with economic growth and development during 1990-2012. The study of Abu et al. (2014) finds that education is an important factor contributes into economic growth of Malaysia during 1975-2013. Odior (2014) evaluate possible effect of government spending policy on education and poverty alleviation in Nigeria. The study finds that the re-allocation of government spending to education sector is vital in determine economic development and the decrease of poverty in Nigeria. Pegkas (2014) investigates the relationship between educational levels and economic development (GDP), where the potential effects of the various educational levels on economic development in Greece for the period of 1960-2009. The empirical results indicate that there is a long-run association between educational levels and economic development. The inclusive result reveals that secondary and higher education have had a significantly positive effect on economic development. Though, the contribution of primary education in economic development found is minimal. The study of Azam and Ather (2015) mention that the findings support the hypothesis of the study by confirming that human capital development is important for economic development of Commonwealth of Independent States over the period 1993- 2011. 


\section{Materials and Method}

This part of the study is based on secondary data. For experimental analysis, annual data covering the period of 1971-72 to 2013-14 are used. The data have been obtained from Federal Bureau of Statistics (FBS) 50 Years of Pakistan in Statistics, State Bank of Pakistan Handbook, 2010, and Government of Pakistan, Economic Survey (2013-14). Where, the data are in thousand on primary, middle and high schools teachers in educational institutions in Pakistan. Similarly, the data on Gross Domestic Product per capita are in constant and million Pak rupees.

In order to investigate the impact of primary school, middle school, and high school teacher on economic development in Pakistan, the following regression model is proposed to be used.

GDPPCI $=\mathrm{f}$ (primary school teachers (PST), middle school teachers (MST), high school teachers (HTT))

Equation (1) can also be written as follows:

$$
G D P P C I=a+b X+e
$$

In the above equations, GDPPCI is per capita GDP as dependent variables, whereas, $\mathrm{X}$ denotes primary school teachers, middle school teachers, and high school teachers which are independent variables. In equation (2) e is error term and show effect of all other factors which are not included in the model. This study used the method of ordinary least squares (OLS) as an analytical techniques for parameters estimation. For computation purpose the EView 3.1 statistical software is used.

\section{Results and Data Analysis}

Results are reported in Table 1, 2, 3 and Table 4 in details. We provide results separately on each independent variable namely primary school teachers, middle school teachers, and high school teachers in order to know about their individual effect on the dependent variable. Table 1 shows descriptive statistics of all variables used in this study. It is evident from Table 1 that maximum per capita GDP of Pakistan is PKR 57.41 million, where the minimum is PKR 788.

Table 1. Descriptive statistics

\begin{tabular}{ccccc}
\hline & GDPPCI & PST & MST & HST \\
\hline Mean & 20.19212 & 297.6721 & 153.9093 & 209.1326 \\
Median & 10.01500 & 332.5000 & 119.0000 & 165.6000 \\
Maximum & 57.41000 & 465.3000 & 373.9000 & 505.1000 \\
Minimum & 0.788000 & 105.7000 & 36.00000 & 40.20000 \\
Std. Dev. & 20.15437 & 131.8553 & 113.5064 & 147.6303 \\
Probability & 0.048475 & 0.073519 & 0.082677 & 0.115122 \\
Observations & 43 & 43 & 43 & 43 \\
\hline
\end{tabular}

Results on the impact of primary school teachers on economic development are given in Table 2. The model is good fit where the coefficient of determination $\left(\mathrm{R}^{2}\right)$ value is 0.74 , it show that 74 variation in the dependent variable explain by the independent variable primary school teachers. Table 2 further reveals that there is a positive and statistically significant relationship between primary school teacher and economic development. The estimated coefficient size is 0.131 , it imply that one unit change in this variable will bring 13 percentage point change in the dependent variables.

Table 2. Regression results on the impact of primary school teachers on economic development

\begin{tabular}{ccccc}
\hline \multicolumn{5}{c}{ Dependent Variable: GDPPCI } \\
\hline \multicolumn{4}{c}{ observations: 43} \\
Variable & Coefficient & Std. Error & t-Statistic & Prob. \\
PST & $0.131906^{*}$ & 0.012061 & 10.93625 & 0.0000 \\
Constant & -19.07268 & 3.919301 & -4.866347 & 0.0000 \\
R-squared & 0.744710 & Mean dependent var & 20.19212 \\
Adjusted R-squared & 0.738483 & S.D. dependent var & 20.15437 \\
S.E. of regression & 10.30669 & F-statistic & 119.6015 \\
\hline
\end{tabular}

Note: Asterisk * show significant al 1 percent level of significance 
Table 3 shows empirical result on the effect of middle school teacher on economic development in Pakistan. The $\mathrm{R}^{2}$ value is 0.98 which reveals that 98 percent variation is explain by the independent variable high school teacher in dependent variable per capita GDP. The effect of middle school on economic development is positive and statistically significant at $1 \%$ level of significance. The estimated coefficient size found is 0.176 , it suggesting that one unit change in this variable will bring 17 percentage unit changes in the dependent variable.

Table 3. Regression results on the impact of middle school teacher on economic development

\begin{tabular}{|c|c|c|c|c|}
\hline \multicolumn{5}{|c|}{ Dependent Variable: GDPPCI } \\
\hline \multicolumn{5}{|c|}{ Observations: 43} \\
\hline Variable & Coefficient & Std. Error & t-Statistic & Prob. \\
\hline MST & $0.176142^{*}$ & 0.003500 & 50.33010 & 0.0000 \\
\hline Constant & -6.917745 & 0.666532 & -10.37871 & 0.0000 \\
\hline R-squared & 0.984072 & \multicolumn{2}{|c|}{ Mean dependent var } & 20.19212 \\
\hline Adjusted R-squared & 0.983684 & \multicolumn{2}{|c|}{ S.D. dependent var } & 20.15437 \\
\hline S.E. of regression & 2.574421 & \multicolumn{2}{|c|}{ F-statistic } & 2533.119 \\
\hline
\end{tabular}

Note: Asterisk * show significant al 1 percent level of significance

Results on the impact of high school teacher on economic development are reported in Table 4 . Where the $\mathrm{R}^{2}$ value is 0.96 , it indicating that 96 percent variation explicate by the independent variable in dependent variable. The influence of high school teacher on economic development is found positive and statistically significant at $1 \%$ level of significance. The coefficient size is 0.133 , implying that one change in high school teachers will bring 13 percentage unit changes in the dependent variable per capita GDP used as measurement for economic development or and/ poverty reduction in Pakistan during the period under the study. These finding reveals that the encouragement human capital through teacher enhancement along with teacher training promotion is highly indispensable for the development of Pakistan and it will certainly mitigate poverty in the country as well.

Table 4. Regression results on the impact of high school teacher on economic development

\begin{tabular}{ccccc}
\hline \multicolumn{4}{c}{ Dependent Variable: PCI } \\
\hline \multicolumn{4}{c}{ Method: Least Squares } \\
Date: $12 / 16 / 14$ & Time: $20: 56$ & \\
Sample: 1972 & 2014 \\
Included observations: 43 & \\
Variable & Coefficient & Std. Error & t-Statistic & Prob. \\
HST & $0.133756^{*}$ & 0.004268 & 31.33738 & 0.0000 \\
Constant & -7.780525 & 1.088396 & -7.148617 & 0.0000 \\
R-squared & 0.959923 & Mean dependent var & 20.19212 \\
Adjusted R-squared & 0.958946 & S.D. dependent var & 20.15437 \\
S.E. of regression & 4.083658 & \multicolumn{2}{c}{ F-statistic } & 982.0315 \\
\hline
\end{tabular}

Note: Asterisk * show significant al 1 percent level of significance

\section{Findings and Conclusion}

The central objective of the present paper is to understand the consequence of education, the significance of teacher in education and its overall influence on the national economic development of Pakistan. It is obvious, that education is a form of wisdom where the knowledge, skill, understanding and behaviors of class people are transferred through education, instruction and training. Therefore, the role of education and teachers' education has become more important to improve human capital and consequently it will have a positive impact on the development and prosperity of any country like Pakistan.

The empirical results of this study reveals that teachers in all level including primary school teachers, middle school teachers and high school teachers play a positive and statistically significant role in promoting national 
economic development and as a results poverty reduction. Therefore, these findings have some important policy implications. The management authorities of Pakistan at federal level and provincial levels needs to pursue prudent and education promoting oriented policy in order to promote education and increase quality trained teachers in the country. Consequently, it will further help to promote overall economy performance and will improve social welfare of the society in the country.

\section{References}

Abu, B. N. A. Haseeb, M., \& Muhammad, A. (2014). The nexus between education and economic growth in Malaysia: cointegration and Toda-Yamamoto causality approach. Actual Problems of Economics, 12(162), $131-141$

Ahmed. (2000). National seminar on education, the dream and reality. Army education directorate, general headquarters and ministry of education, Government of Pakistan.

ASER. (2013). Annual Status of Education Report. Retrieved from http://www.aserpakistan.org/

Azam M., \& Khattak N. (2009). Empirical analysis of the determinants of economic growth in Pakistan; 1971-2005. Sarhad, Journal of Agriculture, 25(2), 307-312.

Azam, M. (2013). Foreign direct investment, financial deepening and economic growth in Azerbaijan and Kazakhstan: a comparative empirical study. The Empirical Economic Letters, 12(6), 611-618.

Azam, M., \& Ather, M. A. (2015). Role of human capital and foreign direct investment in promoting economic growth: evidence from Commonwealth of Independent States. International Journal of Social Economics, 42(2). http://dx.doi.org/10.1108/IJSE-05-2014-0092

Azam, M., Ibrahim, Y., \& Bakhtiar, B. (2014). Foreign direct investment and economic growth in Asia. Actual Problems of Economics, 11(161), 58-67.

Burtch, B. (2006). Education law and social justice. In A. Oduaran, \& H. S. Bhola (Eds.), Widening access to education as social justice Netherland (pp. 83-94): Springer. http://dx.doi.org/10.1007/1-4020-4324-4_5

Cheng, Y., \& Cheung, W. (1997). Multi-model of education quality and multi levels of self-management in schools. Educational Management and Administration, 25(4), 26-37. http://dx.doi.org/10.1177/0263211X 97254008

Datta, A. (1982). Education and Society: Sociology of African Education. London: Macmillan Publisher.

Farah, A., Fauzee, M. S. O., \& Daud, Y. (2014a). A cursory review of the importance of teacher training: a case study of Pakistan. Middle-East Journal of Scientific Research, 21(6), 912-917.

Farah, K., Fauzee, O. M. S., \& Daud, Y. (2014b). Teacher training education programme in three Muslim countries-Afghanistan, Iran and Pakistan. Journal of Education and Human Development, 3(2), 729-741.

Government of Pakistan, Economic Survey of Pakistan. (2013-14). Military of Finance, Islamabad, Pakistan.

Huang, F., Jin, L., \& Sun, X. (2009). Relationship between Scale of Higher Education and Economic Growth in China. Asian Social Science, 5(11), 55-59. http://dx.doi.org/10.5539/ass.v5n11p55

Lasker, R. D., Weiss E. S., \& Miller, R. (2001). Partnership synergy: A practical framework for studying and strengthening the collaborative advantage. The Milbank Quarterly, 79(2), 179-205. http://dx.doi.org/10.1111/1468-0009.00203

Lin, T. (2006). Alternative measure for education variable in an empirical economic growth model: Is primary education less important?. Economics Bulletin, 15, 1-6.

Loening, J., Bhaskara, R., \& Singh, R. (2010). Effects of education on economic growth: Evidence from Guatemala. MPRA Paper 23665, University Library of Munich, Germany.

Mirza, M. S. (2003). Quality of primary education in Pakistan. Islamabad: UNESCO.

Muhammad, A., \& Chandra, E. (2014). The Role of Governance in Economic Development: Evidence from Some Selected Countries in Asia and the Pacific. International Journal of Social Economics, 41(12), 1265-1278. http://dx.doi.org/10.1108/IJSE-11-2013-0262

Muhammad, A., \& Salim, R. (2014). The monetarist hypothesis of inflation in Pakistan - a critique. Journal of the Asia Pacific Economy. http://dx.doi.org/10.1080/13547860.2014.970324

Odior, E. S O. (2014). Government expenditure on education and poverty reduction: implications for achieving the MDGs in Nigeria a computable General Equilibrium Micro-Simulation analysis. Asian Economic and 
Financial Review, 4(2), 150-172.

Ozturk, I. (2001). The role of education in economic development: a theoretical perspective. Journal of Rural Development and Administration, 33(1), 39-47.

Pegkas, P. (2014). The link between educational levels and economic growth: a neoclassical approach for the case of Greece. International Journal of Applied Economics, 11(2), 38-54.

Quran 96:1. The Holy Quran.

Rao, R. R., \& Rao, B. D. (2005). Methods of teacher training (pp. 1-2, 7, 19-20, 42-46, 57, 158-159, 357-359, 376- 377.). Discovery Publishing House, New Dehli, India.

Rashid, K., Abbass, A., Hussain, A., Khalid, N., \& Salfi, A. N. (2014). Perceptions of students about classroom management as a contributing factor towards learning at secondary school. American Research Institute for Policy Development, 3(2), 713-728.

Sarita, \& Tomar, M. (2004). Teacher education: making education effective (pp. 62-63, 231, 254-255, 280). Isha Books, Adarsh Nagar, Dehli, India.

Shah, M. (2002). Comparative effectiveness of teacher training in enhancing the professional attitudes of B. Ed students admitted in institutes of education and research, NWFP, colleges of education Islamabad and Allama Iqbal University, Islamabad (Unpublished M. Phil Thesis, pp. 14-15, 19, 23-25). Allama Iqbal Open University, Islamabad.

Shaihani, M., Harisb, A., Ismaila, N., \& Saida, R. (2011). Long run and short run effects on education levels: case in Malaysia. International Journal of Economic Research, 2(6), 77-87.

Surah Al Bakarah ayat 269. The Holy Quran.

Surah Az zumr-ayah 9. The Holy Quran.

UNESCO. (2000). World education forum: Dakar framework for action 2000. Paris: UNESCO.

\section{Copyrights}

Copyright for this article is retained by the author(s), with first publication rights granted to the journal.

This is an open-access article distributed under the terms and conditions of the Creative Commons Attribution license (http://creativecommons.org/licenses/by/3.0/). 